\title{
Crisis Management Skills of School Administrators in Terms of School Improvement: Scale Development ${ }^{\dagger}$
}

\author{
Aytac Tokel ${ }^{1 *}$, Timucin Ozkan ${ }^{1}$, Gokmen Dagli ${ }^{1}$ \\ ${ }^{1}$ Near East University, Faculty of Education, Institute of Educational Sciences, Nicosia, N. CYPRUS
}

Received 22 September 2017 - Revised 7 October 2017 - Accepted 15 October 2017

\begin{abstract}
The aim of this study is to develop a measurement tool for school administrators to use crisis management skills in terms of school development as pre-crisis (PC), crisis moment (CM) and post-crisis (PC). In the study, the steps of the process carried out for this purpose are explained. In the scale development process, firstly, scanning of the literature was carried out and similar scales were examined. Expert opinion has been consulted for the validity of the scale. The study group of the survey has 216 vocational high school teachers working in North Cyprus in the 2016-2017 school year. Factor analysis was performed to determine the validity of the scale. The results of the factor analysis revealed that the scale factor was a factor and that the total factor variance was $50,211 \%$ for one factor. The reliability coefficient of the scale (Cronbach alpha) was found to be 0.95 . The value of Kaiser-Meyer Olkin (KMO) was found to be 0.917 . Therefore, this scale has led to the conclusion that school administrators can accurately and credibly measure crisis management skills in terms of school development.
\end{abstract}

Keywords: crisis, scale development, school manager, school improvement

\section{INTRODUCTION}

Organizations can see extraordinary situations that suddenly appear over time. These extraordinary situations, which put organizations in trouble, are called crises. It is useful to emphasize the definition of crisis and school development in terms of better understanding of the measurement tool that is being studied. The dictionary meaning of the crisis is, a rough time, depression, crisis in a country or between countries, society or a life of a corporation (TDK, 2014). According to Can (2005), crisis refers to a job, a mixed phase of an event, a difficult situation to get out of, a sudden upsurge and a dangerous moment in the direction of deterioration. Crises are unexpected. Loosemore (1998) defines the crisis as a situation in which an individual, group or organization experiences caused by sudden changes and can not come from above using normal-ordinary methods (Tuğcu, 2004). There is a natural difference between caught prepared and unprepared persons in unexpected situations (Kadıbeşegil, 2003). Özdemir (2002) defines the crisis as a tension situation that threatens its existing values, aims and assumptions by making the adaptation mechanisms inadequate, preventing, anticipating, prompt and urgent responses. On the other hand, Aksoy (2003) expresses the organizational function as the situation that interferes with the functioning of the living organism, disrupting the crisis, disorganization of the organization, obstructing the healthy functioning and intervening. Ogel (2005), the crisis is an unexpected, unforeseen event that requires immediate intervention and resolution, which prevents the individual from performing it's normal functions of the group or organization. What is important for organizations is; It is not to look for ways to postpone the crisis, but rather to feel that the crisis is coming before reached and to complete the pre-crisis preparations, or to get out of the crisis with minimal damage or even some positive results (Narbay, 2005). It is important to know how to prepare for a crisis and how to handle it in the event of a crisis. Precautions should be taken to avoid repetition and early warning systems should be developed. Moreover, it can be said that the manager must follow and analyze the

\footnotetext{
† This work was extracted from the Doctoral Thesis titled “Analysis of Relationship Between Administrative Effectiveness and Organizational Efficiency Behavior of School Administrators" Prepared by Aytac TOKEL under the supervision of Assoc. Prof. Dr.Gokmen DAGLI.
} 


\section{Contribution of this paper to the literature}

- The literature contribution of this study is to develop a measurement tool for school management's crisis management skills in terms of school development.

- School managers' crisis management skills not only distinguish pre-crisis, post-crisis and post-crisis scale from other crisis scales in terms of school development, but they also increase their readiness level for crime.

- This article provides a significant contribution to the literature on school management levels of school managers' crisis management skills.

external environment continuously in order to be prepared and to be protected from crisis. In order for the crisis to be minimized or even beneficial, It can be argued that the causes of the crisis should be based on sound analysis of the dimensions, effects and direction, and that the necessary measures should be taken in place, on time and in a practical way. In the past, the crisis plans at schools were about how the school would be emptied only when there was a gas leak or a fire. Today, schools have to be prepared for car bombings, suicide attempts and armed raids, as well as biological, chemical, and radiological attacks (Brickman et al., 2004). The task of management is to make decisions based on a combination of knowledge and experience. Crises are, naturally, short and unexpected situations that a few managers control with either existing knowledge or practical experience (Parsons, 1996). It is emphasized that a well-managed crisis can be transformed into a frenzy, taking the necessary precautions in advance and taking the crisis with the least harm, and putting the life of the organization and the individuals in danger, can be regarded as a great success (Baran, 2007).

In order to catch the information age and to become a knowledge and technology society, it is necessary to educate the universal thinking, locally behaved human type, to increase the competitiveness of the individual and society continuously and to support the education system with technology education at every stage. In this framework, a new culture of teaching and learning has emerged. Hesapcioglu (2004) suggests that society's expectations and criticism from the school cause the school to change; That the demands and criticisms that lead to new school understandings make it necessary for schools and teachers to develop. Parallel to social development, organizations are also inevitable to change. Especially the education system / schools have to educate the people who generate the society, according to the demands of the society. Developments in public administration also affect organizational structures and constitute the main source of changes in the structural and operational functionsof organizations (Ery1lmaz, 2010).

Organizations do not evolve spontaneously. Organizations develop with the influence of public administration personnel (organization, public policy, financial resources, public officials, norm organization and people). The education system is also influenced by the new public order as the most important element of the society and it has to be a development center where the individuals suitable for the new-world adjustment competencies are trained (Eryılmaz, 2010). According to Rolff (2008), school development moves alongside organizational development and personal development on the one hand, and on the other, within a given system. According to Balc1 (2002), school development is either fairly quantitative directional or direction is quantitative; Dominantly based on the destruction of psychological biased beliefs on non-school factors by quantitative paradigm. School development forces educators to address school cultures, examine beliefs and values, and achieve a common understanding of the desired future for students and schools (Turan, 2006). At the center of school development, there is teaching and teachers, students and parents. Individual schools, the engine of school development, enhance learning and teaching qualityTeachers, parents and students become clear to innovations and changes by following the program clearly and systematically. This makes daily life in school easier and more beneficial. On the other hand, the school takes a position that responds to changing social problems and prepares students well for the future. According to Rolff (2008), this kind of school development, on the one hand moves together with organizational developmentand personal development and on the other hand, within the framework of a certain system.

School development is the period when a failed school becomes successful. For this reason, the desire to change may come from different sources. System-wide changes come from the government, individual school change requests come from local education authorities or the school itself. Under the change, the school may be in crisis or seeking effectiveness(Mortimore, 1993, akt Balc1, 2002 a,).

Van Velzen ao. (1985, Balc1, 2002a) define school development as a systematic effort to change learning conditions and other related internal conditions to achieve educational objectives more effectively in one or more schools. The international school development work regards change in education as a school development approach. This definition foresees careful planning, management and continuity even in difficult situations, teaching and learning orientation, and support for organizational conditions (Balc1, 2007). 


\section{Purpose and Significance}

The purpose of this study is to develop a measurement tool for school managers to determine crisis management skills in terms of school development. Crises are situations that unexpectedly arise and put organizations' assets in danger.

It is possible to survive the crises harmlessly, but be prepared for crises. In our country, studies about the crisis of schools are inadequate. In the literature, there is minute amount about crisis management in schools. The results obtained with this research; It is important that school administrators identify crisis management skills in terms of school development, organize in-service training on crisis management, and emphasize that schools should be more conscious in this regard.

\section{METHOD}

\section{Participants}

The sample of the study consisted of 216 vocational high school teachers in North Cyprus, during 2016-2017 education and training period, and it aimed to develop a measurement tool for "crisis management skills in terms of school managers' school improvment". In this study, stratified random sampling method is used. Stratified random sampling is a process in which a certain number of subgroups for the sample are selected in the same way as the total number (Fraenkel \& Wallen, 2006). For this study, a sample of $48 \%$ of the target population was used. There are 453 vocational teachers from all regions and 216 teachers from five regions (11 schools) surveyed in 20162017 voluntarily agreed to participate. There are evaluations in the literature that there are not a large number of items in the measure and that if the structure of the factors that are revealed is strong, it will have a sample of 100200 persons and that according to common belief the sample group should be at least five times the number of items in the measure (Büyüköztürk, 2002). When the number of items to be measured (33) and the size of the group applied (216) are considered, both criteria are met in terms of sample size to be subjected to factor analysis.

\section{Improvement of Scale}

The purpose of developing the scale is to structure the materials in terms of the subject (Erkuş, 2014). For this reason, in order to measure the teachers' crisis management processes in terms of school development, the scale was firstly established in the preparation phase ofthescale.

\section{Creation of Item Pool}

After the negotiations in the qualitative dimension of the survey, 46 items of the material pool were created by using the project which is also known as the school development project and defined by 10 sub-chapters by Hale (2000). In addition, 16 articles have been written in the related literature, using the work on management processes and crisis management. Thus, a 62-item pool of pre-crisis, crisis moment and post-crisis themes of "crisis management skills in terms of school management's school development" was introduced, taking into consideration the views of the principal and assistant principals selected from the target mass of the scale.

\section{Receive of Expert Opinions for Scope and Appearance Validity}

The indication of whether the material is sufficient in quantity and quality to measure the behavior (characteristic) to be measured is valid in scope (Büyüköztürk, 2011). Expert opinions were received from 6 field experts, using the item opinion form, in order to determine the adequacy of coverage and the adequacy of the items in the repository to measure the managers' crisis management processes in terms of school development. When formulating the Article Opinion Form, firstly, a statement reflecting the scope of the scale and the expectations of the experts was presented. Expert opinions on the suitability of the items for coverage were obtained using a triple rating scale ( 1 point for "Not eligible", 2 points for "Partially eligible", 3 points for "Completely eligible"). When determining the appropriateness of the material, the average score of each item was calculated and compared with the actual upper limit of the appropriate option at mid-point of 2.5 (K1lıç Çakmak, Güneş, Çiftci and Üstündağ, 2011).

According to Erkus (2014), in the method of examination of empirical and statistical substances, the items which the experts have agreed to remain, some are passed by eye, others are discarded. Accordingly, 22 items with an average score less than 2.5 were excluded, 6 items were arranged and 40 items were obtained. The items are randomly arranged on the data collection tool. All the written materials were examined by a faculty member of Atatürk Faculty of Education with a PhD degree in order to evaluate Turkish language appropriateness. 
Table 1. OYOGKYBÖKMO and Bartlett Test result for the scale

\begin{tabular}{cc}
\hline \multicolumn{2}{c}{ KMO and Bartlett Test Result } \\
\hline Kaiser-Meyer-Olkin Measure of Sampling Adequacy & .917 \\
\hline Bartlett's Test of Sphericity Approx. Chi-Square & 6339.684 \\
\hline $\mathrm{df}$ & 528 \\
\hline Sig. & .000 \\
\hline
\end{tabular}

A statement of purpose for the draft scale and a directive reflecting expectations from the participants were prepared. Awareness statements were scaled by a five-point Likert scale. Likert type grades; It is in the form of "Always (5)", "Mostly (4)", “Sometimes (3)", “ Rarely (2)", “Never (1)". For items containing all positive expressions, "Always" corresponds to 5points and "Never" corresponds to 1 point. As the total score obtained from the scale increases, the evaluation scores of teachers' crisis management processes and school development also increase. All materials contain positive expressions. Finally, the draft scale, prepared for the preliminary experiment, was evaluated by three faculty members with a doctoral degree experienced in scale development. In this process, in the direction of expert opinions; Whether it is an expression of awareness, the way in which the materials are expressed, the suitability for the purpose of the work, and the validity of the scope. In a scale-up trial, the sample should only represent the extent of the measured characteristic, be heterogeneous and consist strictly of voluntary participants (Erkuş, 2014). According to this, with the draft scale prepared for the preliminary experiment, the volunteer teachers were implemented in the schools at vocational high school level. Karasar (2012), states that the number of participants for the preliminary trial in the course of the development of a scale should not be less than 50. Preliminary trial application was carried out with a 40-item draft scale and 220 participants.

\section{Collection of Data}

The data were collected by the researcher after 7 days of training. A preliminary trial was conducted with a total of 220 participants. The mean response time of the scale was 20 minutes. At the end of the application, 4 missing questionnaires were not evaluated and a total of 216 participants returned the questionnaire.

\section{Analysis of Data}

SPSS 23.0 was used to analyze the data obtained from the application of the scale in response to responses from a total of 216 teachers who agreed to participate in the study. First, your scale is tested for validity and reliability. Kaiser-Meyer-Olkin (KMO) and Bartlett test (BTS) were applied to determine the suitability of the data for analysis. Significant increases in $\mathrm{KMO}$ and a significant Bartlett test indicate that the data are appropriate for factor analysis. In the scope of the research, the sample size required for factor analysis was examined and the study group was found sufficient (Tabachnick \& Fidell, 2001). The construct validity factor analysis and internal consistency reliability test of the scale were examined by Cronbach's alpha coefficient. An exploratory factor analysis was performed to examine the validity of the structure of the scale. According to Tavşancil (2006), factor analysis is one of the multivariate analysis techniques used to define the order between each item and the responses of respondents and to define the content of psychological dimensions.

\section{FINDINGS AND COMMENTS}

After the answers of the teachers were collected, the validity of the scale was examined. Factor analysis was applied to determine the validity of the structure of the scale. In the factor analysis, Kaiser-Meyer-Olkin (KMO) and Bartlett (BTS) tests were performed to determine the adequacy of the data obtained from the sample. The KMO value obtained in this study is .917. This value indicates that the data obtained are suitable for factor analysis (Table 1).

Factor analysis was conducted to determine which of the 40 attitude items were appropriate for the scale. The distinction of each substance (substance-total test correlations) was examined. The item-test correlations, first factor loads and substance averages were calculated and the item test correlation was significant $(\mathrm{p}<0.05)$. The factor load value was determined as 0.45 , and it was found that 7 items remained below this value. The factor analysis was repeated for each item, starting with the item with the lowest factor value. Factor load values ranging from .454 to .831 in one dimension of the remaining materials after 7 items are removed are shown in Table 2. 
Table 2. Factor Load Values of the Items

\begin{tabular}{|c|c|c|c|c|c|c|c|c|c|c|c|c|c|c|c|c|c|}
\hline BC8 & .831 & CM6 & .806 & AC20 & .794 & AC8 & .744 & $\mathrm{BC2}$ & .706 & BC9 & .694 & AC1 & .649 & BC16 & .602 & CM13 & .454 \\
\hline CM2 & .822 & AC19 & .804 & CM1 & .775 & AC3 & .743 & AC7 & .705 & CM17 & .693 & BC19 & .648 & BC15 & .549 & & \\
\hline BC21 & .807 & CM8 & .796 & CM18 & .774 & AC15 & .739 & BC20 & .702 & AC11 & .686 & BC1 & .618 & CM4 & .549 & & \\
\hline CM2O & .806 & AC21 & .796 & CM10 & .745 & CM19 & .727 & AC16 & .695 & BC4 & .656 & BC5 & .609 & AC6 & .506 & & \\
\hline
\end{tabular}

Table 3. Total Variance Values Explained for the Matters (33 items)

\begin{tabular}{|c|c|c|c|c|c|c|}
\hline \multirow[b]{2}{*}{ Component } & \multicolumn{3}{|c|}{ Initial Eigenvalues } & \multicolumn{3}{|c|}{ Extraction Sums of Squared Loadings } \\
\hline & Total & $\%$ of Variance & Cumulative \% & Total & $\%$ of Variance & Cumulative $\%$ \\
\hline 1 & 16.569 & 50.211 & 50.211 & 16.569 & 50.211 & 50.211 \\
\hline 2 & 1.937 & 5.870 & 56.081 & & & \\
\hline 3 & 1.673 & 5.068 & 61.149 & & & \\
\hline 4 & 1.439 & 4.361 & 65.510 & & & \\
\hline 5 & 1.214 & 3.678 & 69.188 & & & \\
\hline 6 & 1.129 & 3.422 & 72.611 & & & \\
\hline 7 & .918 & 2.782 & 75.393 & & & \\
\hline 8 & .817 & 2.476 & 77.868 & & & \\
\hline 9 & .759 & 2.300 & 80.169 & & & \\
\hline 10 & .684 & 2.072 & 82.241 & & & \\
\hline 11 & .571 & 1.732 & 83.972 & & & \\
\hline 12 & .538 & 1.630 & 85.602 & & & \\
\hline 13 & .481 & 1.457 & 87.059 & & & \\
\hline 14 & .437 & 1.324 & 88.383 & & & \\
\hline 15 & .417 & 1.262 & 89.646 & & & \\
\hline 16 & .385 & 1.166 & 90.812 & & & \\
\hline 17 & .332 & 1.005 & 91.817 & & & \\
\hline 18 & .282 & .856 & 92.672 & & & \\
\hline 19 & .276 & .837 & 93.510 & & & \\
\hline 20 & .250 & .759 & 94.268 & & & \\
\hline 21 & .238 & .723 & 94.991 & & & \\
\hline 22 & .227 & .689 & 95.680 & & & \\
\hline 23 & .219 & .665 & 96.345 & & & \\
\hline 24 & .203 & .614 & 96.959 & & & \\
\hline 25 & .172 & .521 & 97.480 & & & \\
\hline 26 & .155 & .470 & 97.950 & & & \\
\hline 27 & .138 & .417 & 98.367 & & & \\
\hline 28 & .117 & .355 & 98.722 & & & \\
\hline 29 & .114 & .346 & 99.068 & & & \\
\hline 30 & .096 & .291 & 99.360 & & & \\
\hline 31 & .078 & .237 & 99.597 & & & \\
\hline 32 & .071 & .215 & 99.812 & & & \\
\hline 33 & .062 & .188 & 100.000 & & & \\
\hline
\end{tabular}

A total of 33 items remained after 7 items were taken from 40 items.

The scree plot graph is also examined to determine whether the "school managers" scale of 33 items is single or multi-factor in the scale of crisis management skills in terms of school development". As shown in the scree plot graph (Figure 1), the slope makes the plateau after the first point. At this point, the cutoff point for the number of factors was determined as one (Çokluk, Şekercioğlu and Büyüköztürk; 2010). When Figure 1 is examined, a high acceleration decline is observed after the first factor. This shows that you have a general factor of your scale. Based on these results, it was decided that OYOGKYÖÖ should be one-dimensional. 


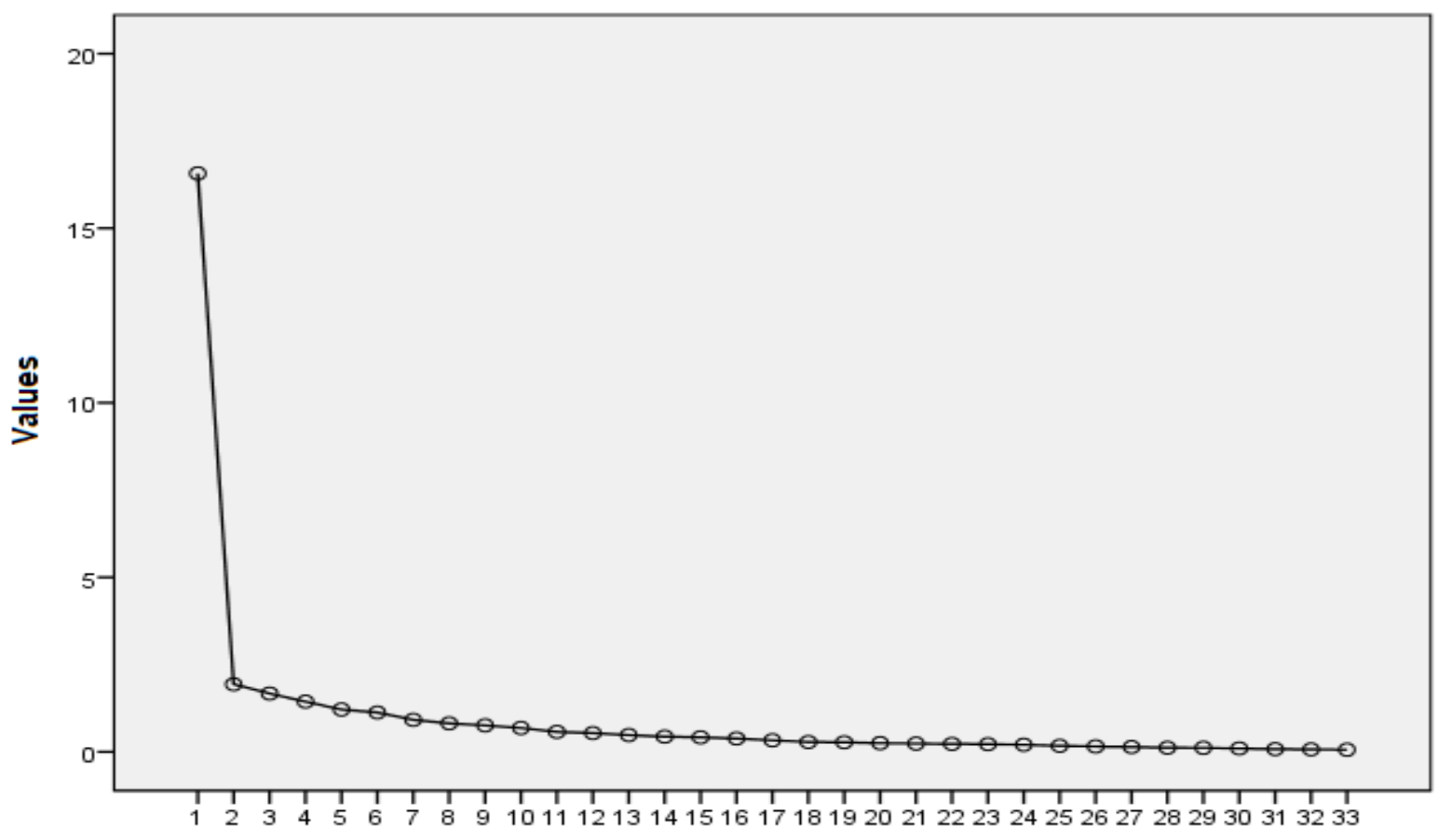

Figure 1. OYOGKYBÖ Scree Plot Chart

In the reliability analysis of OYOGKYBO, the Cronbach alpha value of all scales was calculated and found to be .95. The Guttman split-half coefficient obtained by the split-half method is .92 . The fact that this coefficient is close to 1 indicates that the reliability of the scale is high.For this reason, it is possible to say that your scale has a high level of reliability.

\section{CONCLUSION}

In this study, it was aimed to develop a valid, reliable and useful new scale covering all of these, by examining the scales related to crisis management skills which consist of different and various sub-dimensions in the literature. It is thought that this scale, which can be considered as a step towards the development of similar scales, can be used as a reliable measurement tool for revealing the relations between the variables related to the school for researchers and a guide for subsequent studies. It can be said that the scale is more understandable in language and more economical in practice than similar measuring instruments currently in use. This makes the scale different from the others and provides convenience for practitioners. To determine the factor structure of the adapted scale, it was decided to keep the scale of 33 items measuring a specific construct as a result of the factor analysis. The results of factor analysis show that there is a factor of scale. Thus, this scale contributes to the literature review by a measure of the ability of school managers to measure the scale of crisis management skills in terms of school development. Findings related to the validity and reliability of the scale indicate that school managers have a measure of the quality of crisis management skills in terms of school development. The Cronbach alpha reliability coefficient of the scale was measured as 0.95 . This result shows that the school manager's scale of crisis management skills in terms of school development is valid and reliable. However, the school management's crisis management skills are too dimensional to be limited by a single dimension in the study. More comprehensive school managers' crisis management skills scale with different variables can be developed.

\section{REFERENCES}

Aksoy, H. H., \& Aksoy, N. (2003). Okullarda Krize Müdahale Planlaması. Ankara University, Journal of Faculty of Educational Sciences, 36(1-2).

Balc1, A. (2002). Etkili okul: kuram, uygulama ve araştırma. Ankara: Pegem. 
Balc1, A. (2004). Etkili okul geliştirme kuram uygulama ve araştırma. Ankara: Pegem A.

Baran, H. (2007). İşletmelerde kriz yönetimi. Retrieved on 16 May 2017 from 4855-B351ADCE4362AFE/4491/hitaykriz1.pdf

Brickman, H. K., Jones, S. E., \& Groom, S. E. (2004). Evolving School- Crisis Management Since 9/11. Education Digest, 0013127, 69(9), 29-35.

Büyüköztürk, Ş. (2002). Faktör Analizi: Temel Kavramlar ve Ölçek Geliştirmede Kullanımı. Kuram ve Uygulamada Ĕ̈itim Yönetimi, 32.

Büyüköztürk, Ş. (2011). Sosyal bilimler için veri analizi el kitabi (14. Bask1). Ankara: Pegem Akademi.

Can, H. (2005). Organizasyon ve Yönetim. Ankara: Siyasal Kitabevi.

Çokluk, Ö., Şekercioğlu, G., \& Büyüköztürk, Ş. (2010). Sosyal Bilimler İçin Çok Değişkenli İstatistik: SPSS ve Lisrel Uygulamalar. Ankara: Pegem Akademi.

Ekici, G.(2005). The validity and reliability of the biology selfefficacy instrument. Hacettepe University Journal of Education, 29, 85-94.

Erkuş, A. (2014). Psikolojide ölçme ve ölçek geliştirme I: Temel kavramlar ve işlemler (2.Baskı). Ankara: Pegem Akademi. Eryılmaz, B. (2010). Kamu yönetimi. Ankara: Okutman.

Fraenkel, J. R., \& Wallen, N. E. (2006). How to design and evaluate research in education. New York: McGraw-Hill.

Hale, S. H. (2000). Comprehensive School Reform Research-baseb Strategies to Achieve High Standards. San Fransisco: West Ed.

Hesapçığlu, M. (2004). Eğitim ve okul alanındaki çağdaş gelişmeler ve bu gelişmelerin eğitim yönetimine yansımaları. Yaşadıkça Ĕ̆itim Dergisi, 82, 7- 14.

Kadıbeşegil, S. (2003). Kriz Geliyorum Der! Kriz İletişimi ve Yönetimi. İstanbul: Mediacat Yayınları.

Karasar, N. (2012). Bilimsel araştırma yöntemi: kavramlar, ilkeler, teknikler. Ankara: Nobel Yayın Dağıtım.

Kılıç Çakmak, E., Güneş, E., Çiftci, S., \& Üstündağ, M. T. (2011). Web sitesi kullanılabilirlik ölçeğinin geliştirilmesi: Geçerlik, güvenirlik analizi ve uygulama sonuçları. Pegem Eğitim ve Öğretim Dergisi, 1(2), 31-40.

Loosemore, M. (1998). Organisational behaviour during a construction crisis. International Journal of Project Management, 16(2), 115-121.

Narbay, M. Ş. (2005). Kriz İletişiminde Halkla İlişkilerin Rolü (Unpublished Masters Thesis). Dokuz Eylül Üniversitesi. Sosyal Bilimler Enstitüsü.

Ögel, K., Tarı, I., \& Eke, C. Y. (2006). Okullarda Suç Ve Şiddeti Önleme. İstanbul: Yeniden Yayınları.

Özdemir, T. A. (2002). İlköğretim Okul Müdürlerinin Kriz Yönetimi Konusundaki Koordinasyon Yeterliliklerinin Değerlendirilmesi (Unpublished Masters Thesis). Abant İzzet Baysal Üniv., Sosyal Bilimler Enstitüsü, Düzce.

Parsons, W. (1996). Crisis Management. Career Development International, 1(5), 26-28.

Rolff, H. G. (2008). Konzepte und Verfahren der Schulentwicklung. Fernstudium Schulmanagement, Studienbrief SEM0810, Kaiserslautern, 1-32.

Sayıl, I. (1992). Olağanüstü Koşullarda Krize Müdahalenin Yeri ve Önemi, Kriz Dergisi, 1(1).

Tabachnick, B. G., \& Fidell, L. S. (2001). Using multivariate statistics (4th Ed). Needham Heights: Allyn\& Bacon.

Tuğcu, Ş. T. (2004). Kriz Yönetiminde Liderlik Kavramının Önemi. Selçuk Üniversitesi, İletişim Fakültesi Dergisi, 3 , 16-22.

Turan, S. (2006). Yarınların Türkiyesi İçin Okulu Yeniden Tasarlamak ve Düşünmek. Eğitim-Bir-Sen (Ed.), Türk Eğitim Sisteminde Yeni Paradigma Arayışları Sempozyum Bildiriler Kitabı, 306-317.

Türk Dil Kurumu Sözlüğü. (2014). Retrieved on 16 May 2017 from tdk.gov.tr/index.php?option=com

\section{http://www.ejmste.com}

